\title{
Klædd eða nakin? Áhrif nektar á viðhorf til auglýsinga
}

\author{
Soffía Halldórsdóttir, Auður Hermannsdóttir og Kári Kristinsson ${ }^{1}$
}

\begin{abstract}
Ágrip
Eigi auglýsingar að ná pví markmiði að hafa áhrif á neytendur er mikilvægt að viðhorf til peirra sé jákvætt. Síðastliðna áratugi hefur orðið markviss aukning í notkun kynferðislegra tenginga í auglýsingum, en slíkar tengingar spanna allt frá óljósum vísbendingum og tvíræðni, til ögrandi framkomu og algerrar nektar. Niðurstöður fyrri rannsókna um áhrif slíkra tenginga á viðhorf til auglýsinga hafa verið misvísandi auk pess sem flestar rannsóknanna hafa snúið að viðhorfi neytenda pegar um kvenkyns fyrirsætu er að ræða. Rannsókninni var ætlað að bregðast við pessu ósamræmi í niðurstöðum fyrri rannsókna og skorti á rannsóknum sem snúa að karlskyns fyrirsætum. Markmiðið var að kanna áhrif nektar á viðhorf til auglýsinga, annars vegar pegar fyrirsætan er kvenkyns og hins vegar pegar hún er karlkyns. Notað var 2 (klædd, nakin) x 2 (karlfyrirsæta, kvenfyrirsæta) tilraunasnið. Pátttakendum ( $\mathrm{n}=1349)$ voru sýndar auglýsingar sem innihéldu annað hvort nakta fyrirsætu eða klædda fyrirsætu, ýmist karlkyns eða kvenkyns, og voru svo beðnir að svara spurningum um viðhorf sitt til auglýsinganna. Niðurstöðurnar gefa til kynna að nekt hafi neikvæð áhrif á viðhorf til auglýsinga, hvort sem fyrirsætan er karlkyns eða kvenkyns. Pessi neikvæðu áhrif áttu við um bæði kvenkyns- og karlkyns pátttakendur en viðhorf kvenkyns pátttakenda eru sérstaklega neikvæð pegar um nakta kvenkyns fyrirsætu er að ræða. Niðurstöðurnar benda pví til að auglýsendur ættu ekki að nota nekt í auglýsingum til að ná athygli neytenda, sér í lagi ef markhópurinn er konur.
\end{abstract}

\section{Abstract}

If ads are to achieve their goal of influencing consumers, it is important that consumers' attitude towards them is positive. In recent decades, there has been a significant increase in the use of sexual appeal in advertising, all from vague hints and ambiguity, to provocative content and nudity. Previous studies on the influence of such appeal on attitude towards ads have shown conflicting results and most of them have focused on ads where female models are used. This study was intended to address the inconsistency in previous studies and lack of studies including male models. The purpose was to investigate the effects of nudity on participants' attitude towards ads, both when the model is female and when it is male. A 2 (dressed vs. nude) x 2(male model vs. female model) experimental design was applied. Participants $(n=1349)$ were shown ads that contained either a naked model or a dressed model, either male or female, and were than asked questions regarding

1 Soffía Halldórsdóttir er innkaupastjóri Össur á Íslandi. Netfang: soffiah@internet.is. Auður Hermannsdóttir er aðjunkt við Viðskiptafræðideild Háskóla Íslands. Netfang: auh1@hi.is. Kári Kristinsson er prófessor við Viðskiptafræðideild Háskóla Íslands. Netfang: karik@hi.is.

This work is licensed under a Creative Commons Attribution 4.0 License.

DOI: https://doi.org/10.24122/tve.a.2020.17.1.1 
their attitude towards the ad. The results indicate that nudity has a negative impact on attitude towards ads, both in case of a male model and a female model. This negative effect applies to both female and male participants, but the attitudes of female participants are particularly negative in the case of a nude female model. Advertisers are therefore advised against using nudity in ads to attract consumer attention, especially if the target audience is women.

JEL flokkun: M31, M37

Lykilorð: Auglýsingar, viðhorf til auglýsinga, nekt, kynferðislegar tengingar

Keywords: Advertisments, attitude towards ads, nudity, sexual appeal

\section{Dressed or Naked? The Influence of Nudity on Attitude to- wards Ads}

\section{Inngangur}

Auglýsingar eru ein af peim aðferðum sem hægt er að nýta í markaðssamskiptum par sem auglýsandi greiðir fyrir að koma á framfæri ópersónulegum og ógagnvirkum upplýsingum (Egan, 2015). Meginhlutverk auglýsinga er að koma á framfæri upplýsingum og hafa áhrif á neytendur. Upplýsingar sem gjarnan koma fram í auglýsingum eru t.d. verð, hvar sé hægt að kaupa tiltekna vöru eða pjónustu og gagnsemi vörunnar eða pjónustunnar. Lokamarkmið peirra er pó ávallt að hafa áhrif á neytendur, t.d. hvað varðar vitund, ímynd, tryggð og að endingu að peir kaupi tiltekna vöru eða pjónustu (Reichert, 2007; Reichert, LaTour og Kim, 2007). Рað hvort tiltekin auglýsing hafi raunverulega áhrif á neytendur er meðal annars háð viðhorfi peirra til auglýsingarinnar (Fam, 2008; Mackenzie og Lutz, 1989; Mehta, 2000; Prendergast, Liu og Poon, 2009) og er pá átt við neikvætt eða jákvætt tilfinningalegt mat einstaklings á auglýsingunni (Muehling og McCann, 1993; Spears og Singh, 2004). Neikvætt viðhorf til auglýsingar getur pannig komið í veg fyrir að markmiði auglýsingarinnar verði náð (Beard, 2003; Calfee og Ringold, 1988) sem leiðir til sóunar á auðlindum fyrirtækisins. Рað er pví mikilvægt að neytendur, sér í lagi markópurinn sem auglýsingunni er beint að, hafi jákvætt viðhorf til auglýsingarinnar ef hún á að ná peim markmiðum sem stefnt er að.

Síðastliðna áratugi hefur orðið markviss aukning í notkun kynferðislegra tenginga í auglýsingum (Davies, 2011; Reichert og Carpenter 2004; LaTour og Henthorne, 1993; Soley og Read, 1988). Um kynferðislegar tengingar er að ræða pegar vörumerkjaskilaboðin eru sett fram með kynferðislegum hætti, ýmist sjónrænt, munnlega eða pau rituð (Reichert og Carpenter, 2004; Reichert, Heckler og Jackson, 2001; Reichert o.fl., 2007), en pessar tengingar geta spannað allt frá óljósum vísbendingum og tvíræðni, til ögrandi framkomu og algerrar nektar (Reichert og Carpenter, 2004). Auglýsendur nota kynferðislegar tengingar af mörgum ástæðum. Fyrst og fremst til að vekja athygli á skilaboðum sínum og vörumerki (Alexander og Judd, 1986; Belch, Holgerson, Belch og Koppman, 1982; Bello, Pitts og Etzel, 1983; Dudley, 1999; MacInnis, Moorman og Jaworski, 1991; Reichert og Carpenter, 2004; Reichert o.fl., 2001; Severn, Belch og Belch, 1990; Sparks og Lang, 2015) en einnig til að höfða til neytenda sem finnast slíkar tengingar spennandi og til að undirstrika hver „útkoman“ yrði fyrir neytandann ef hann keypti og notaði vörurnar peirra (Percy og Rossiter, 1992; Reichert og Carpenter, 2004). Мeð öðrum orðum, neytandinn myndi upplifa sömu nautn eða losta og fyrirsætan sem auglýsingin sýnir (LaTour og Henthorne, 1993). Auglýsendur nota einnig kynferðislegar tengingar af samkeppnisástæðum; peir vilja að auglýsingin peirra standi út úr fjöldanum í auglýsingaflóðinu hverju sinni, nái og haldi atygli áhorfenda með раð аð lokamarkmiði að auka sölu (Reichert, 2007).

En er notkun kynferðislegra tenginga í auglýsingum ákjósanleg? Er hún líkleg til ár- 
angurs? Hvaða áhrif hefur slík tenging á viðhorf neytenda til auglýsingarinnar og par með á mögulegan árangur auglýsingarinnar? Niðurstöður fyrri rannsókna hafa verið misvísandi. Sumar rannsóknir hafa sýnt að varhugavert geti verið að í auglýsingum sé sýnd mjög mikil nekt (LaTour og Henthorne, 1993; van Niekerk og Jenkinson, 2013) par sem slíkt geti beint athygli neytenda í of miklum mæli að myndefni auglýsingarinnar á kostnað annarra skilaboða (Alexander og Judd, 1978; Grazer og Keesling, 1995) og að neytendum geti pótt auglýsingarnar ósæmandi (Prendergast og Hwa, 2003). Á meðan sumar rannsóknir hafa sýnt að notkun kvennektar í auglýsingum sé síður líkleg til árangurs pegar markhópurinn er konur fremur en karlar (Dianoux og Linhart, 2010; LaTour, 1990; LaTour og Henthorne, 1993; LaTour, Pitts og Snook-Luther, 1990) hafa aðrar rannsóknir bent til pess að konum pyki auglýsingar góðar pótt pær sýni konur á kynferðislegan hátt (Choi, Yoo, Reichert og LaTour, 2016; Zimmerman og Dahlberg, 2008). Pegar kemur að karlnekt hafa sumar rannsóknir bent til pess að slíkt sé líklegt til árangurs pegar markhópurinn er konur (Baker og Churchill, 1977; Reidenbach og McCleary, 1983; Simpson, Horton og Brown, 1996) á meðan aðrir rannsakendur hafa komist að pví að svo sé ekki (Wan, Luk og Chow, 2014). Petta misræmi í niðurstöðum fyrri rannsókna kallar á frekari rannsóknir á efninu. Að auki hafa flestar rannsóknir sem snúa að nekt og kynferðislegum tengingum í auglýsingum einblínt á kvenkyns fyrirsætur, en mun minna hefur farið fyrir rannsóknum á karlnekt auglýsingum (Baker og Churchill 1977; Peterson og Kerin, 1977; Reidenbach og McCleary, 1983; Simpson o.fl., 1996).

Rannsókninni er ætlað að bregðast við ósamræmi í niðurstöðum fyrri rannsókna og skorti á rannsóknum sem snúa að karlnekt. Markmiðið er að kanna áhrif nektar í auglýsingum á viðhorf til auglýsinga, annars vegar pegar fyrirsætan er kvenkyns og hins vegar pegar hún er karlkyns. Rannsóknin er pví framlag til auglýsingafræðanna en hún er ekki síður mikilvæg auglýsendum í pví skyni að peir geri sér grein fyrir hvort notkun nektar sé ákjósanleg og líkleg til pess að auglýsingin verði árangursrík.

\section{Kynferðislegar tengingar í auglýsingum}

Upphaf rannsókna á sviði kynferðislegra tenginga í auglýsingum og áhrifanna sem pær hafa má rekja til viðleitni rannsakenda til að skilja og útskýra mögulega gagnsemi slíkra tenginga (sjá til dæmis Alexander og Judd, 1978; Peterson og Kerin, 1977; Steadman, 1969). Mikilvægar spurningar í rannsóknum á sviðinu hafa snúist um hvort kynferðisleg skilaboð í auglýsingum séu áhrifarík, hvort pau veki athygli, hvort neytendum líki pau og muni eftir peim ásamt pví hvort kynferðislegar tengingar auki eða hindri úrvinnslu neytenda á auglýsingum. Ef kynferðislegar tengingar bæta úrvinnslu, er auglýsingin meira sannfærandi og ætti að leiða til aukinna viðskipta (Eisend og Tarrahi, 2016; MacInnis o.fl., 1991; Severn o.fl., 1990), ef pær hins vegar hindra úrvinnslu, mun neytandinn vera bæði ófær um og ófús til að kaupa auglýsta vöru eða vörumerki og pá er um sóun á fjármagni að ræða (Reichert, 2002).

Flestar rannsóknir á sviði auglýsinga með kynferðislegar tengingar staðfesta pað sama; að slíkar auglýsingar dragi að athygli neytandans umfram pær sem ekki innihalda kynferðislegar tengingar; pær pykja áhugaverðar, meira aðlaðandi og fanga athygli neytandans (Alexander og Judd, 1978; Alexander og Judd, 1986; Belch o.fl., 1982; Bello o.fl., 1983; Dudley, 1999; MacInnis o.fl., 1991; Reichert o.fl., 2001; Reichert og Carpenter, 2004; Severn o.fl., 1990; Sparks og Lang, 2015; Steadman, 1969). Svokölluð tilfinningaleg svörun á sér stað pegar neytendur sjá auglýsingu sem inniheldur kynferðislegar tengingar, p.e. örvun sem verður til sem viðbrögð við áreiti í umhverfinu (Reichert, 2002). Rannsóknir hafa sýnt að neytendur hafa jákvætt viðhorf gagnvart auglýsingu ef peir upplifa almenna jákvæða örvun við áhorf en hafa neikvætt viðhorf ef peir upplifa spennu eða neikvæða örvun (LaTour 1990; Sciglimpaglia, Belch og Cain, 1979). Hins vegar kann að vera að jákvæða örvunin sem neytendur upplifa við kynferðislegar tengingar í auglýsingum trufli pá í að 
meðtaka skilaboð auglýsingarinnar. Kynferðislegu tengingarnar virðast gjarnan beina athygli neytenda í of miklum mæli að myndefni auglýsingarinnar á kostnað vörumerkjaskilaboðanna (Alexander og Judd, 1978; Grazer og Keesling, 1995) par sem neytandinn einblínir um of á myndefnið en missir af sjálfum skilaboðunum. Ef raunin er sú, eru kynferðislegu tengingarnar ekki að ná pví markmiði sem peim er ætlað (Reichert, 2002) par sem úrvinnsla á skilaboðunum verður ekki eins og til var ætlast (McInnis o.fl., 1991).

Ýmsir pættir hafa áhrif á viðhorf neytenda til auglýsinga sem innihalda kynferðislegar tengingar og mögulegan ávinning af pví að nýta slíkar tengingar. Sálfræðileg viðhorf hafa til dæmis áhrif (Chang, 2006; Chang og Tseng, 2013; Choi o.fl., 2016; Mittal og Lassar, 2000; Reichert, 2002; Reichert o.fl., 2007), líkt og viðhorf til kynferðislegs frjálsræðis (Mittal og Lassar, 2000), kynferðissjálfsvitund (Reichert o.fl., 2007) og viðhorf til femínisma (Choi o.fl., 2016).

Раð hversu viðeigandi kynferðistengingin er fyrir auglýsta vöru eða pjónustu hefur jafnframt áhrif (Peterson og Kerin, 1977; Reichert o.fl., 2001; Simpson o.fl., 1996). Ef varan eða pjónustan sem um ræðir er í eðli sínu á einhvern hátt tengd kynferðislegum páttum eru áhrifin líklegri til að vera meiri (Severn o.fl., 1990). Auglýsendur virðast almennt gera sér grein fyrir pessu enda sýndi rannsókn Reichert, Childers og Reid (2012) að notkun kynferðislegra tenginga er mismikil eftir vöruflokkum. Niðurstöður peirra leiddu í ljós að slíkar tengingar eru mikið notaðar til að auglýsa heilsu- og hreinlætisvörur, ferðalög og skemmtanaiðnaðinn. Niðurstöðurnar sýndu jafnframt að algengt er að nota kynferðislegar tengingar í auglýsingum sen snúa snyrtivörum, ilmvötnum og fatnaði, enda hafa sumir haldið fram að slíkar tengingar séu orðin viðtekin venja í tískuiðnaðinum (Choi o.fl, 2016). Kynferðislegar tengingar eru meira notaðar til að auglýsa ódýrari vöruflokka eða vörur sem parfnast ekki ígrundaðrar ákvörðunar af hálfu neytandans við kaup eins og til dæmis sjampó eða undirfatnað en sjást minna í auglýsingum sem auglýsa vörur sem krefjast ígrundaðrar ákvörðunar eins og til dæmis fjármálapjónustu og tölvubúnað.

Djarfleiki kynferðislegu tenginganna hefur einnig áhrif á viðhorf neytenda (LaTour og Henthorne, 1993), en aukinn djarfleiki leiðir til aukinnar örvunar neytenda. Kynferðislegar tengingar í auglýsingum geta verið litlar eða miklar. Dæmi um litla tengingu er bílaauglýsing par sem aðlaðandi kvenkyns fyrirsæta stillir sér upp við hlið bílsins og er pannig ætlað að draga athygli að auglýsingunni. Á hinn bóginn getur kynferðislega tengingin verið órjúfanlegur hluti af vörumerkjaskilaboðunum; til dæmis ilmvatnsauglýsing par sem kona og maður eru sýnd í innilegum atlotum. Par er kynferðislega tengingin ekki bara órjúfanlegur hluti af skilaboðunum; hún er skilaboðin. Auglýsingin er að segja markhópnum að ef hann noti ilmvatnið muni hann auka líkur sínar á peirri upplifun sem auglýsingin sýnir (Reichert, 2002). Neytendur sem eru að leita að „slíkri útkomu“ eru mun líklegri til að taka eftir og bregðast við slíkum kynferðislegum skírskotunum í auglýsingum (Reichert, 2007). Margar rannsóknir benda til pess að ýktar kynferðislegar tengingar geti haft skaðleg áhrif á viðhorf til auglýsingarinnar og að hætta sé á að hneyksla neytandann, sérstaklega konur (Davies, 2011; Grazer og Keesling, 1995; LaTour o.fl., 1990; Severn o.fl., 1990; Simpson o.fl., 1996).

\section{Kynin og nekt}

Stærstur hluti auglýsinga sem innihalda kynferðislegar tengingar sýna konur frekar en karla í mislitlum, ögrandi og kynferðislegum klæðnaði (Davies, 2011; Eaton, 1997; Mittal og Lassar, 2000; Reichert, 2002; Soley og Read, 1988). Kvennekt hefur verið notuð í síauknum mæli í auglýsingum síðan upp úr 1960 (Reichert og Carpenter, 2004). Notkun á karlnekt í auglýsingum hófst seinna og í minna mæli, en auglýsendur eins og Calvin Klein og Coca Cola riðu á vaðið (Reidenbach og McCleary, 1983; Simpson o.fl., 1996). Í rannsókn Reichert og Carpenter frá árinu 2004 kom í ljós að nær helmingur kvenkyns fyrirsæta voru klæddar á kynferðislegan hátt eða naktar samanborið við 28\% árið 1983. Aftur á móti voru flestar karlkyns fyrirsætur fullklæddar árið 2003, eða 79\% og hélst pað hlutfall tiltölu- 
lega óbreytt frá árinu 1983. Рað er pví ljóst að kynferðislegar tengingar eru orðnar meira áberandi en áđur (Zimmerman og Dahlberg, 2008) en aukningin snýr fyrst og fremst af aukningu á notkun nektar kvenkyns fyrirsæta.

Kyn neytenda er einn af peim páttum sem skiptir verulega máli í viðhorfum til auglýsinga með kynferðislega tengingu (LaTour, 1990; LaTour og Henthorne, 1993; Reichert, 2007; Sciglimpaglia o.fl., 1979). Fjölmargar rannsóknir greina frá mismunandi viðhorfum karla og kvenna til kvennektar í auglýsingum (Alexander og Judd, 1986; Ford og LaTour, 1993; LaTour, 1990; LaTour og Henthorne, 1993; LaTour og Henthorne, 1994; LaTour o.fl., 1990; Maciejewski, 2004), en mun færri rannsóknir hafa snúið að viðhorfum til karlnektar (Baker og Churchill 1977; Peterson og Kerin, 1977; Reidenbach og McCleary, 1983; Simpson o.fl., 1996).

Karlar eru jákvæðari gagnvart kvennekt í auglýsingum en konur og upplifa gjarnan jákvæða orku (Alexander og Judd, 1986; Belch o.fl., 1982; Grazer og Keesling, 1995; LaTour og Henthorne, 1993; LaTour og Henthorne, 1994; LaTour o.fl., 1990; Maciejewski, 2004; Peterson og Kerin, 1977) á meðan konur upplifa frekar spennu eða andúð við að sjá kvennekt (Ford og LaTour, 1993; LaTour, 1990). Samskonar kynjabjögun kemur fram í rannsóknum par sem viðhorf til karlnektar er skoðað par sem konur eru mun jákvæðari gagnvart lítið klæddum karlkyns fyrirsætum en karlar (Peterson og Kerin, 1977; Reidenbach og McCleary, 1983; Simpson o.fl., 1996). Viðhorf bæði karla og kvenna til auglýsinga með kynferðislegar tengingar er pannig jákvæðara gagnvart fyrirsætu af gagnstæðu kyni, en fyrirsætu af sama kyni (Reichert o.fl., 2007), en jafnframt virðist vera sem konur meti kvennekt jákvæðar en karlar karlnekt (Dudley, 1990; Reichert, 2002).

T1: Nakin karlkyns fyrirsæta hefur neikvæðari áhrif á viðhorf til auglýsingar en klædd karlkyns fyrirsæta

T2: Nakin kvenkyns fyrirsæta hefur neikvæðari áhrif á viðhorf til auglýsingar en klædd kvenkyns fyrirsæta

T3: Nakin karlkyns fyrirsæta hefur neikvæðari áhrif á viðhorf karla til auglýsingar en klædd karlkyns fyrirsæta.

T4: Nakin kvenkyns fyrirsæta hefur neikvæðari áhrif á viðhorf kvenna til auglýsingar en klædd kvenkyns fyrirsæta.

T5: Nakin karlkyns fyrirsæta hefur neikvæðari áhrif á viðhorf karla til auglýsingar en kvenna.

T6: Nakin kvenkyns fyrirsæta hefur neikvæðari áhrif á viðhorf kvenna til auglýsingar en karla.

\section{Aðferð}

Markmið rannsóknarinnar var að skoða áhrif nektar í auglýsingum á viðhorf til auglýsinga. Notað var tilraunasnið með 2 (klædd, nekt) x 2 (karlkyns fyrirsæta, kvenkyns fyrirsæta). Í pessum kafla verður greint frá pátttakendum, mælitæki og framkvæmd rannsóknarinnar.

\subsection{Pátttakendur}

Notað var rafrænt hentugleikaúrtak við framkvæmd rannsóknarinnar og eftir fremsta megni reynt að ná til fjölbreytts hóps bæði karla og kvenna á öllum aldri. Hentugleikaúrtak hefur pann kost að auðveldara er að ná í stóran hóp pátttakenda en par sem ekki er notað slembið úrtak er erfitt að álykta um pýðið. Alls tóku 1349 pátt í könnuninni. Tæp $40 \%$ pátttakenda voru karlar og rúm $60 \%$ konur. Aldursdreifing var ágæt par sem um $20 \%$ 
pátttakenda voru 30 ára eða yngri, um 30\% voru á milli 31 til 40 ára, tæp 30\% 41 til 50 ára og rúm $20 \%$ pátttakenda voru eldri en 50 ára.

\subsection{Mælitæki}

Mælitæki rannsóknarinnar skiptist í tvo hluta. Í fyrri hlutanum birtist pátttakendum með tilviljun ein af fjórum ljósmynduðum auglýsingum frá bandaríska fatahönnuðinum og -framleiðandanum Calvin Klein. Talið er að ytra rannsóknarréttmæti rannsóknar aukist við að nota raunverulegt vörumerki frekar en ímyndað vörumerki (Choi, Yoo, Hyun Baek, Reid og Makias, 2013). Vörumerkið Calvin Klein varð fyrir valinu par sem pað er pekkt tískufatamerki og samræmi milli vörunnar og kynferðislegu tenginganna er til staðar. Tvær auglýsinganna sýndu karlkyns fyrirsætu, ýmist nakta eða klædda og tvær auglýsinganna sýndu kvenkyns fyrirsætu, ýmist nakta eða klædda. Par sem raunverulegar auglýsingar voru notaðar var ekki möguleiki að nota sömu fyrirsætur (sjá viðauka), en reynt var að hafa auglýsingarnar eins áferðasvipaðar og mögulegt var.

Í seinni hlutanum var viðhorf pátttakenda til auglýsingarinnar metið. Notað var mælitæki frá Muehling og McCann (1993) par sem viðhorfið var metið með fimm atriðum á sjö punkta raðkvarða. Atriðin voru pýdd yfir á íslensku af höfundum. Sem dæmi um atriði má nefna "Hversu slæm eða góð fannst pér auglýsingin" og „Hversu illa eða vel líkaði pér auglýsingin". Við úrvinnslu var atriðunum fimm steypt saman í eina breytu sem nefnd var „Viðhorf til auglýsingar", $\alpha=0,926$. Mælitækið var forprófað á fimm einstaklingum sem komu með ábendingar um uppsetningu og orðalag. Að lokum var spurt um kyn og aldur pátttakenda.

\subsection{Framkvæmd}

Rafrænum spurningalista var dreift á samfélagsmiðlinum Facebook og áhersla lögð á að dreifa honum sem víðast til að ná til fjölbreytts hóps pátttekenda. Samfélagsmiðillinn Facebook er í síauknum mæli notaður við gagnaöflun, m.a. vegna vinsælda og mikillar útbreiðslu miðilsins. Rannsóknir hafa leitt í ljós að notkun miðilsins við gagnaöflun sé ákjósanleg og jafnvel fýsilegri en aðrar aðferðir við öflun hentugleikaúrtaks (Casler, Bickel og Hackett, 2013; Rife, Cate, Kosinski og Stillwell, 2016; Thorntorn o.fl., 2016)

Í kynningartexta var pátttakendum sagt að könnunin væri liður í rannsókn á viðhorfi neytenda til auglýsinga. Í lok könnunarinnar gafst pátttakendum kostur á að skrá netfang sitt og taka pannig pátt í happdrætti. Happdrættið var notað sem hvati til að auka svörun en verðlaunin voru 10.000 króna gjafabréf í Kringluna. Könnunin var opin dagana 4. - 10. apríl 2019. Send voru regluleg skilaboð á Facebook á pví tímabili og fólk hvatt til að svara og deila spurningalistanum.

\section{Niðurstöður}

Markmið rannsóknarinnar var að skoða áhrif nektar í auglýsingum á viðhorf til peirra. Tilgáturnar gerðu ráð fyrir að nekt hefði neikvæð áhrif á viðhorf til auglýsingar og voru pví notuð einhliða tilgátupróf. Tilgáturnar gerðu jafnframt ráð fyrir að sú niðurstaða ætti meira við kvenkyns en karlkyns neytendur pegar um nakta kvenkyns fyrirsætu væri að ræða og að sama skapi ætti meira við karlkyns heldur en kvenkyns pátttakendur pegar um karlkyns fyrirsætu væri að ræða.

Tilgáta 1 gerir ráð fyrir að nekt karlkyns fyrirsætu hefði neikvæð áhrif á viðhorf til auglýsingar (hærra gildi táknar jákvæðara viðhorf). Eins og sést á mynd 1 var töluverður munur á viðhorfi pátttakenda til auglýsingar eftir pví hvort peir sáu karlkyns fyrirsætu $(M$ $=4,11, S F=1,15)$ eða nakta karlkyns fyrirsætu $(M=3,30, S F=1,37)$. Pessi munur reyndist marktækur, $t(265)=5,28, p<0,001, d=0,71$. Petta styður pví tilgátu 1 um að nekt karlkyns fyrirsætu hafi neikvæð áhrif á viðhorf til auglýsinga. Áhugavert er að munur á viðhorfi pátttakenda er töluverður. Samkvæmt áhrifastuðli (e. effect size) er pessi munur metinn sem miðlungs sterkur (Cohen, 1988). 


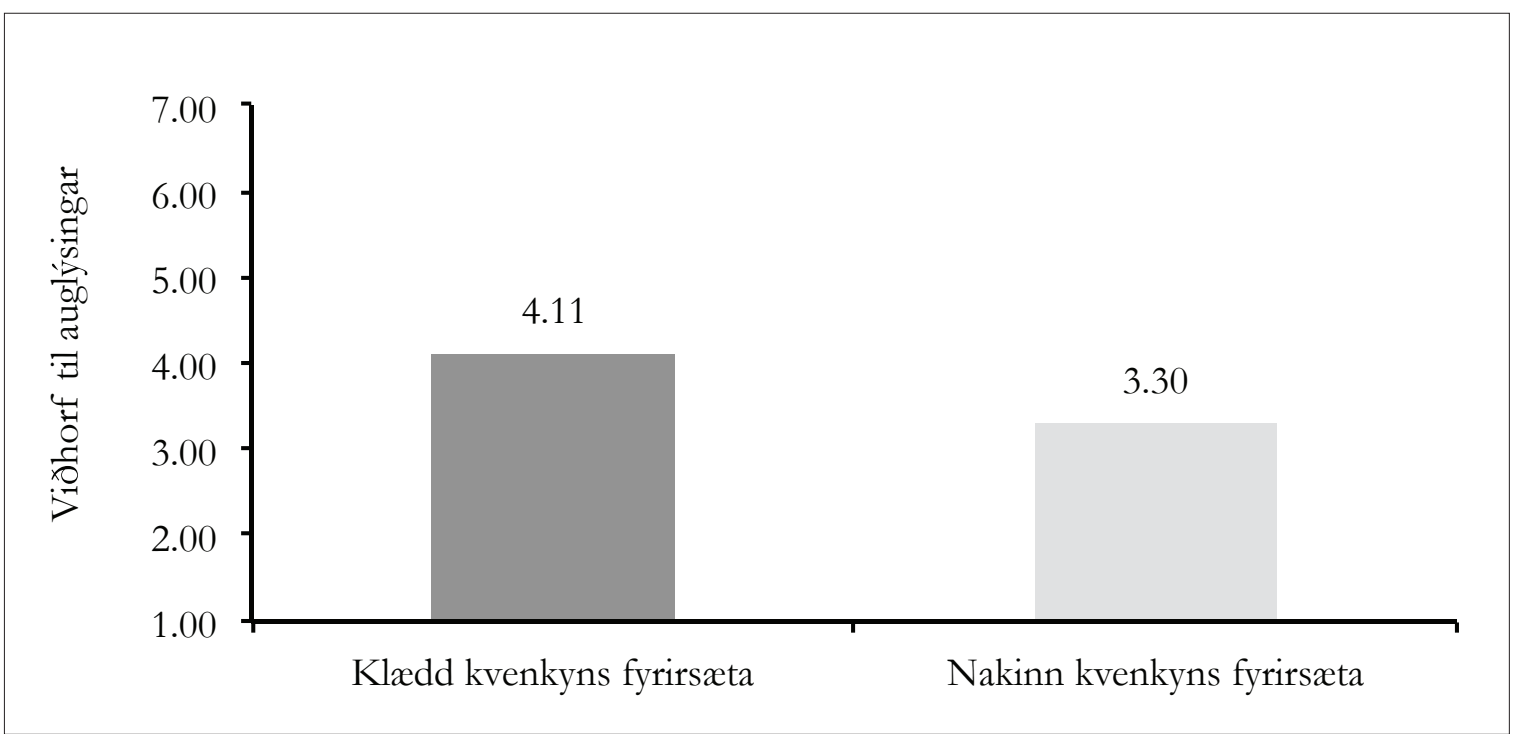

Mynd 1. Viðhorf til klæddrar og nakinnar karlkyns fyrirsætu.

Tilgáta 2 hélt fram að kvenkyns nekt hefði neikvæð áhrif á viðhorf til auglýsingar. Eins og mynd 2 sýnir var viðhorf neytenda jákvæðara pegar kvenkyns fyrirsæta var klædd $(M$ $=3,99, S F=1,36)$ en pegar kvenkyns fyrirsæta var nakin $(M=2,96, S F=1,60), t(287)=5,99$, $p<0,001, d=0,69$. Tilgáta 2 um neikvæðara viðhorf til auglýsingar með naktri kvenkyns fyrirsætu en klæddri fyrirsætu var pví studd. Áhrifastærð er metinn sem miðlungs sterk.

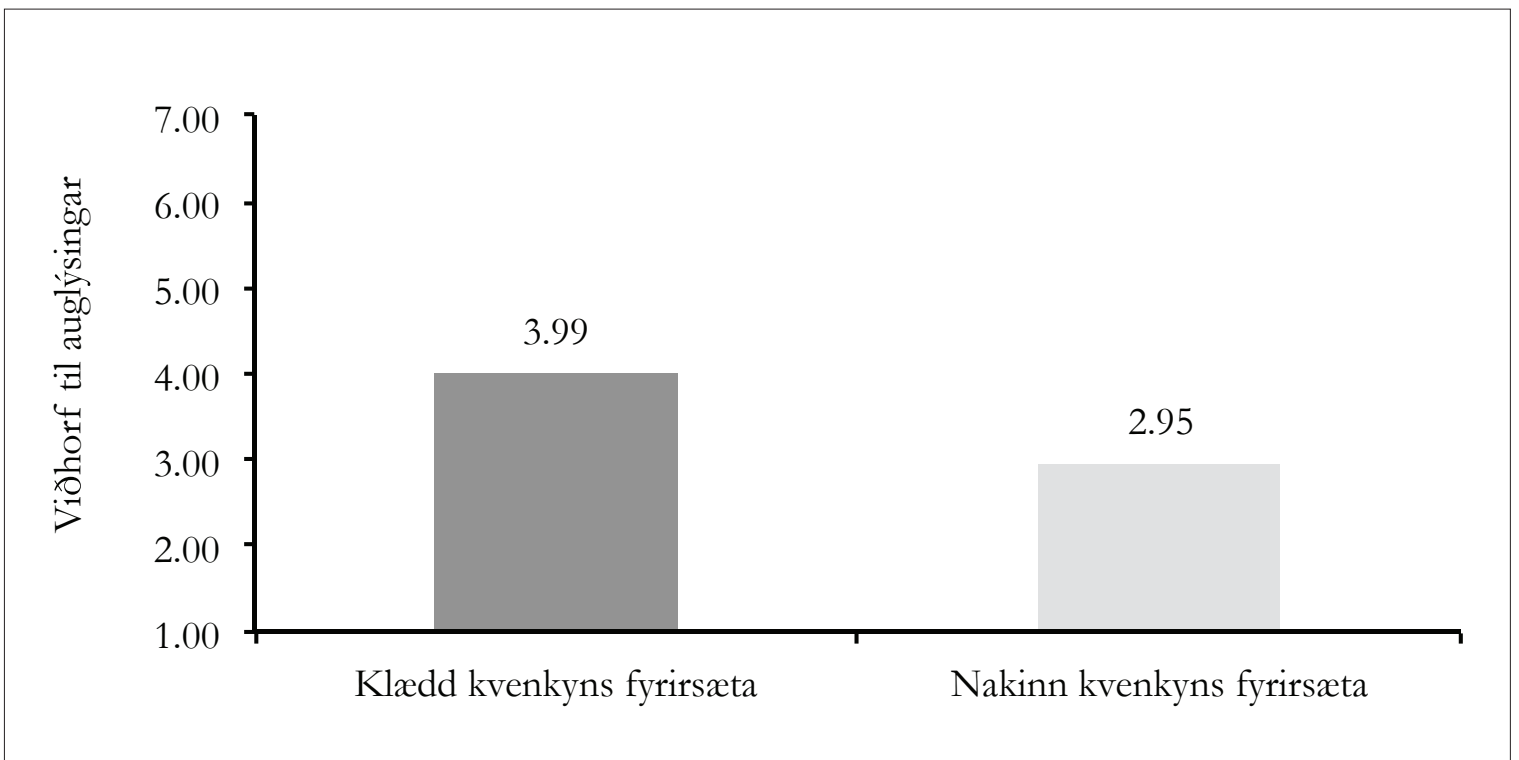

Mynd 2. Viðhorf til klæddrar og nakinnar kvenkyns fyrirsætu.

Tilgáta 3 sneri að pví að karlkyns neytendur væru með neikvæðara viðhorf gagnvart auglýsingu sem sýndi nakta karlkyns fyrirsætu heldur en klædda. Eins og sést á mynd 3 voru pátttakendur sem sáu auglýsingu með karlkyns nekt með neikvæðara viðhorf $(M=3,35$, $S F=1,47)$ en peir pátttakendur sem sáu samskonar auglýsing með klæddri karlkyns fyrirsætu $(M=4,21, S F=1,07)$ og var sá munur marktækur, $t(77)=3,00, p=0,002, d=0,67$. Petta styður pví tilgátu 3 um að karlar hafi neikvæðara viðhorf til auglýsinga sem sýna karlkyns nekt. Samkvæmt áhrifastuðli er pessi munur metinn sem miðlungs sterkur. 


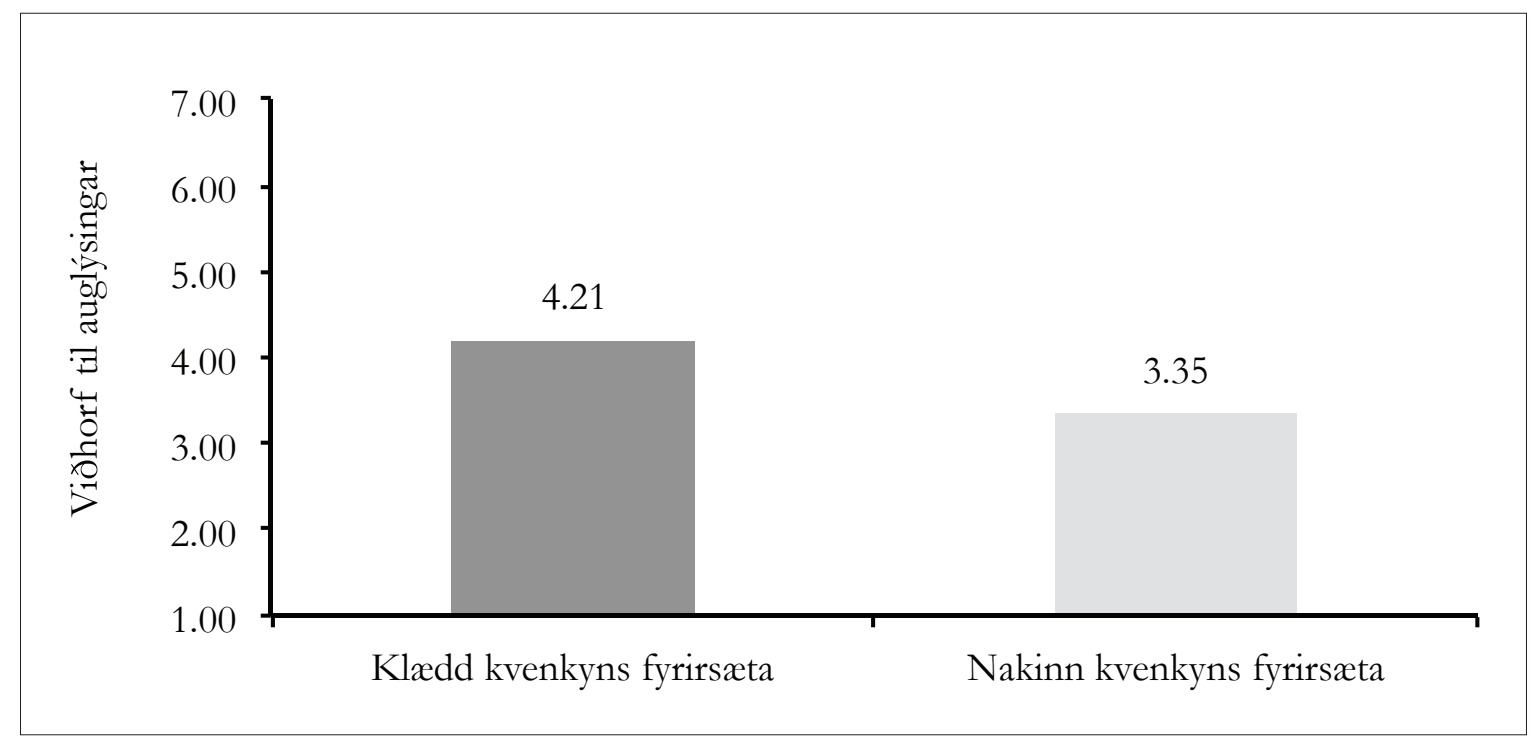

Mynd 3. Viðhorf karlkyns pátttakenda til karlnektar í auglýsingum.

Tilgáta 4 var um að kvenkyns pátttakendur væru með neikvæðara viðhorf gagnvart auglýsingum með kvenkyns nekt heldur en peim auglýsingum sem sýndu ekki kvenkyns nekt. Eins og sést á mynd 4 voru pátttakendur sem sáu auglýsingar með kvenkyns nekt voru með neikvæðara viðhorf gagnvart auglýsingu $(M=2,51, S F=1,37)$ en peir pátttakendur sem sáu samskonar auglýsingu með klæddri kvenkyns fyrirsætu $(M=4,20, S F=$ $1,45), t 146)=7,30, p<0,001, d=1,20$. Petta styður pví tilgátu 4 um að konur hafi neikvæðara viðhorf til auglýsinga með kvenkyns nekt. Samkvæmt áhrifastuðli er pessi munur á viðhorfi til auglýsinga mikill.

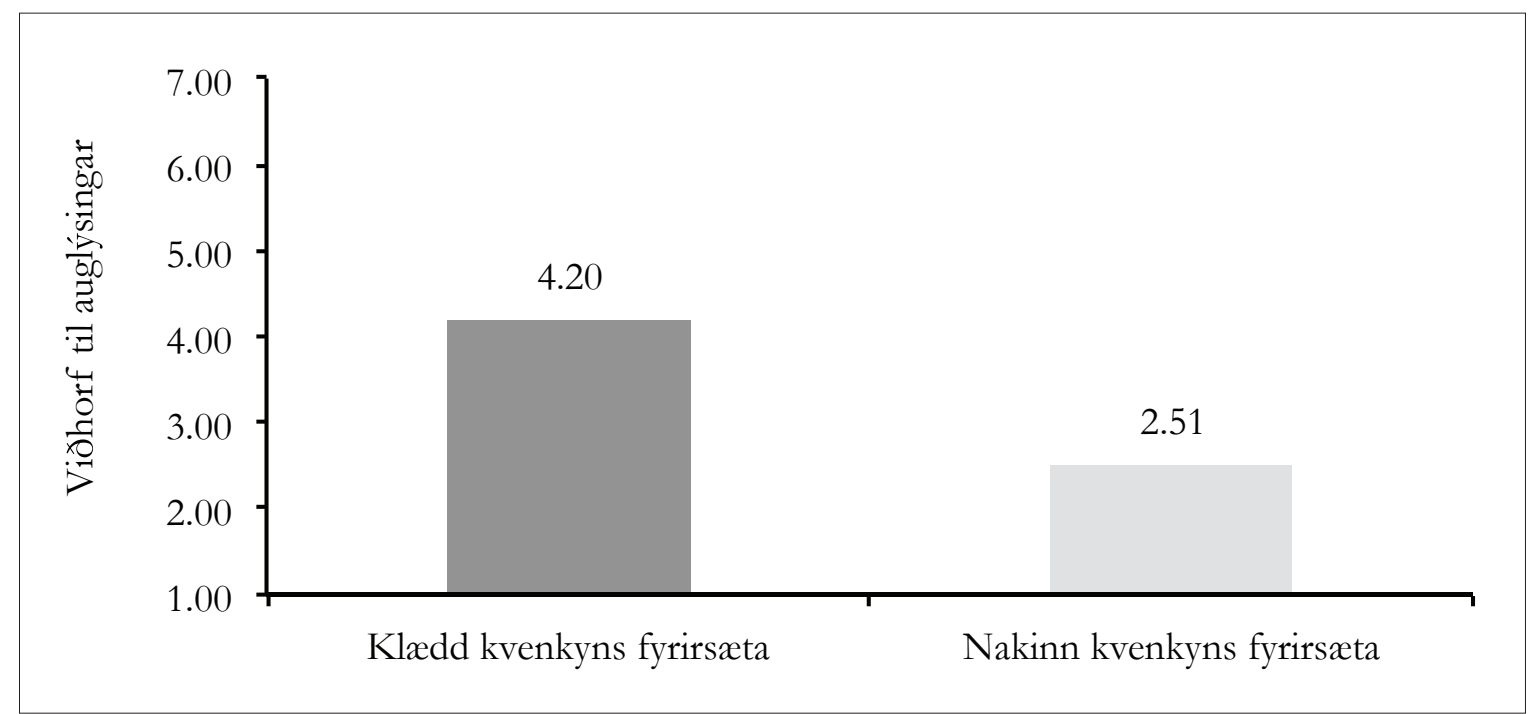

Mynd 4. Viðhorf kvenkyns pátttakenda til kvennektar í auglýsingum.

Tilgátur 5 og 6 snúa að mun milli karl og kvenkyns pátttakenda pegar kemur að auglýsingum sem sýna nekt. Eins og sjá má á mynd 5 er ekki munur á milli karlkyns $(M=3,35$, $S F=1,47)$ og kvenkyns pátttakenda $(M=3,29, S F=1,13)$ pegar kemur að karlkyns nekt 1 auglýsingum, $t(114)=, 22, p=0,41$. Ef hinsvegar kvennekt í auglýsingu er skoðuð finnst er munur á viðhorfi á milli kvenkyns $(M=2,51, S F=1,37)$ og karlkyns $(M=3,61, S F=1,56)$ pátttakenda pegar kemur að viðhorfi til auglýsingar og er sá munur marktækur, $t(119)=$ $4,04, p<0,001, d=0,75$. 


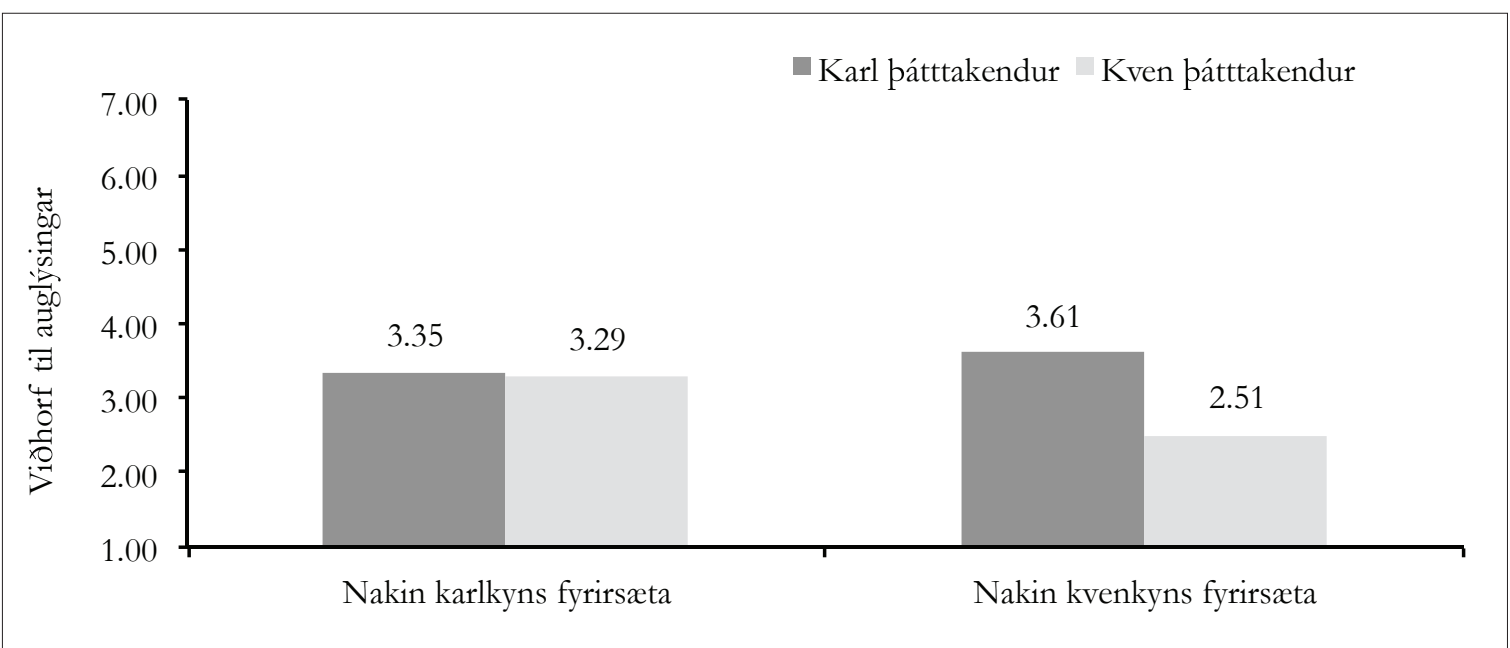

Mynd 5. Viðhorf pátttakenda til nektar af sitthvoru kyni.

Til að skoða niðurstöðuna úr tilgátum 5 og 6 betur var athugað hvort samvirkni væri milli kyns pátttakenda og naktra fyrirsæta af sitthvoru kyni. Eins og mynd 6 gefur til kynna var samvirknin til staðar og marktæk, $F(1,233)=7,99, p=0,005$.

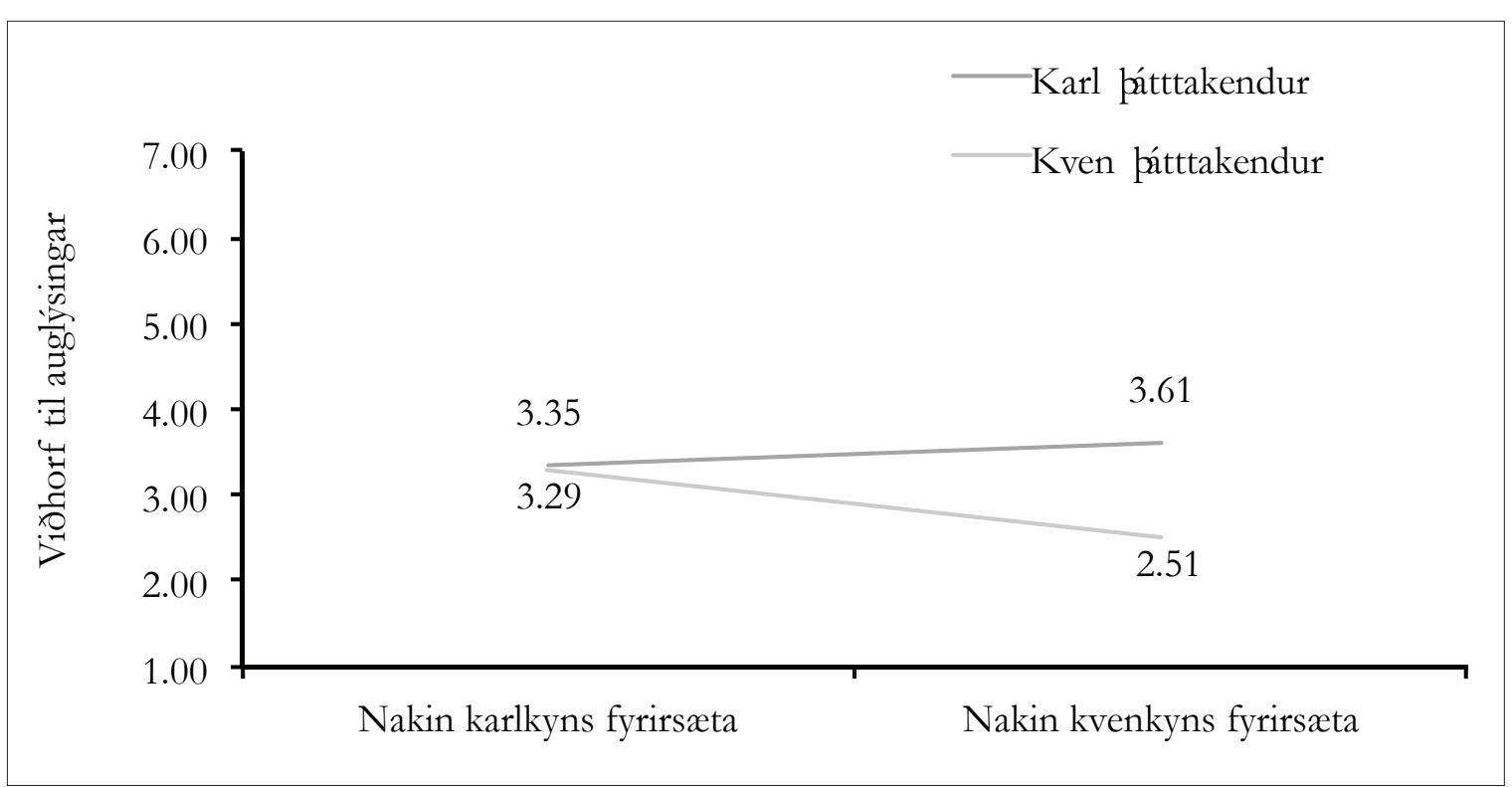

Mynd 6. Viðhorf pátttakenda og samvirkni milli kyns pátttakenda og nektar af sitthvoru kyni.

Í heildina bentu niðurstöðurnar til að bæði karlnekt og kvennekt hefðu neikvæð áhrif á viðhorf til auglýsinga. Sérstaklega á pað við um kvennekt hjá kvenkyns pátttakendum pó svo að öll nekt virðist hafa neikvæðari áhrif á mat neytenda heldur en pegar henni er sleppt.

\section{Umræða}

Markmið auglýsinga er að hafa áhrif á neytendur, en hvort pað markmið næst eða ekki er meðal annars háð viðhorfi peirra til auglýsinganna (Fam, 2008; Mehta, 2000; Prendergast, Liu og Poon, 2009). Síðastliðna áratugi hafa auglýsendur í síauknum mæli notað kynferðislegar tengingar í auglýsingum (Davis, 2011; Reichert og Carpenter 2004; LaTour og Henthorne, 1993), sér í lagi til að ná athygli neytenda (Alexander og Judd, 1986; Dudley, 
1999; Reichert og Carpenter, 2004; Reichert o.fl., 2001; Sparks og Lang, 2015). Niðurstöður fyrri rannsókna um hvort slík tenging sé líkleg til að hafa jákvæð eða neikvæð áhrif á viðhorf neytenda til auglýsinga hafa verið misvísandi. Að auki hafa áherslur í fyrri rannsóknum að mestu leyti snúið að auglýsingum með kvenkyns fyrirsætu en mun færri rannsóknir hafa snúið að áhrifum pess að nota auglýsingar með kynferðislega tengingu pegar fyrirsætan er karlkyns. Rannsókninni var ætlað að bregðast við pessu ósamræmi í niðurstöðum fyrri rannsókna og skorti á rannsóknum sem snúa að karlskyns fyrirsætum. Markmiðið var að kanna áhrif nektar í auglýsingum á viðhorf til auglýsinga, annars vegar pegar fyrirsætan er kvenkyns og hins vegar pegar hún er karlkyns.

Niðurstöðurnar studdu tilgátu 1 og tilgátu 2 og sýndu að viðhorf til auglýsinga var neikvæðara pegar fyrirsætan var nakin en pegar hún var klædd. Petta var raunin bæði pegar um karlkyns fyrirsætu og kvenkyns fyrirsætu var að ræða. Kynferðislegar tengingar og djarfleiki í auglýsingum getur verið mismikill, en stig djarfleika hefur áhrif á viðhorf neytenda og hefur áhrif á hversu mikil örvun neytandans verður við pað að sjá auglýsinguna (LaTour og Henthorne, 1993). Nakin fyrirsæta er líkleg til að kalla fram töluverða örvun í samanburði við t.d. fyrirsætu í ögrandi klæðnaði. Hins vegar er ekki sjálfgefið að mikil örvun sé jákvæð, hún getur jafnframt verið neikvæð og kallað fram neikvæða spennu. Á meðan jákvæð örvun er líkleg til að hafa jákvæð áhrif á viðhorf til auglýsingar en neikvæð örvun að sama skapi líkleg til að hafa neikvæð áhrif (LaTour 1990; Sciglimpaglia o.fl., 1979). Miðað við niðurstöður rannsóknarinnar er líklegt að neytendur upplifi frekar neikvæða örvun pegar fyrirsætan er nakin sem hefur pá neikvæð áhrif á viðhorfið til auglýsingarinnar. Petta samræmist niðurstöðum fyrri rannsókna sem hafa sýnt að ýktar kynferðislegar tengingar geti haft skaðleg áhrif á viðhorf til auglýsingarinnar (Davies, 2011; Grazer og Keesling, 1995; LaTour o.fl., 1990; Severn o.fl., 1990; Simpson o.fl., 1996).

Tilgáta 3 var einnig studd en hún snéri að karlkyns neytendum. Niðurstöðurnar sýndu að peir eru neikvæðari gagnvart auglýsingu sem sýnir nakta karlkyns fyrirsætu en klædda karlkyns fyrirsætu. Petta samræmist niðurstöðum fyrri rannsókna sem sýna að karlar eru frekar neikvæðir gagnvart auglýsingum með lítið klæddum karlkyns fyrirsætum (Baker og Churchill, 1983; Peterson og Kerin, 1977; Reidenbach og McCleary, 1983; Simpson o.fl., 1996). Sama var uppi á teningnum pegar tilgáta 4 var könnuð, en hún snéri að viðhorfum kvenkyns neytenda til kvenkyns fyrirsæta. Tilgátan var studd par sem niðurstöðurnar sýndu að konur höfðu neikvæðara viðhorf til auglýsinga sem sýndu nakta kvenkyns fyrirsætu en auglýsinga sem sýndu klædda kvenkyns fyrirsætu. Sambærilegar niðurstöður hafa komið fram í fyrri rannsóknum (Alexander og Judd, 1986; Ford o.fl., 1994; LaTour og Henthorne, 1994; LaTour o.fl., 1990; Maciejewski, 2004) sem talið er orsakast af pví að konur upplifi spennu eða andúð við að sjá kvennekt í auglýsingum (Ford og LaTour, 1993; LaTour, 1990).

Tilgátur 5 og 6 snéru að mun á viðhorfum karlkyns og kvenkyns neytenda til auglýsinga sem sýna nekt. Tilgáta 5, sem snéri að pví að nakin karlkyns fyrirsæta hefði neikvæðari áhrif á viðhorf karla til auglýsinga heldur en kvenna, var ekki studd. Niðurstöðurnar sýndu að ekki var munur á viðhorfum kynjanna pegar um karlnekt var að ræða. Petta er í andstöðu við fyrri rannsóknir sem hafa sýnt að konur eru mun jákvæðari gagnvart lítið klæddum karlkyns fyrirsætum en karlar (Baker og Churchill, 1983; Peterson og Kerin, 1977; Reidenbach og McCleary, 1983; Simpson o.fl., 1996). Hins vegar studdu niðurstöðurnar tilgátu 6 um að nakin kvenkyns fyrirsæta hefði neikvæðari áhrif á viðhorf kvenkyns neytenda til auglýsinga en karlkyns neytenda, sem samræmist fyrri rannsóknum (Belch o.fl., 1981; Grazer og Keesling, 1995; LaTour og Henthorne, 1993; Peterson og Kerin, 1977).

Heilt yfir sýna niðurstöðurnar að djarfar auglýsingar sem sýna nakta fyrirsætu, hvort sem um er að ræða karlkyns eða kvenkyns fyrirsætu, hafi neikvæð áhrif á viðhorf pátttakenda til auglýsinga. Ef auglýsingum er ætlað að hafa áhrif á neytendur er mikilvægt að viðhorf peirra til auglýsinganna sé jákvætt. Niðurstöður rannsóknarinnar eru mikilvægar auglýsingafólki. Pær sýna að ekki sé líklegt til árangurs að nýta nekt til að ná athygli neyt- 
enda og að pað geti verið sérstaklega varhugavert pegar auglýsingarnar eru miðaðar að kvenkyns neytendum.

Niðurstöðurnar byggjast á hentugleikaúrtaki og fyrir vikið er ytra rannsóknarréttmæti ekki eins og best verður á kosið. Hins vegar er orsakasamhengið ljóst vegna tilraunasniðs og fjöldi pátttakenda töluverður með ágætri skiptingu milli kynja og aldurshópa. Niðurstöðurnar ættu pví að gefa góðar vísbendingar um samanburð á viðhorf neytenda til auglýsinga sem annars vegar sýna nekt og hins vegar ekki. Jafnframt kann að vera ákveðin takmörkun að nýta pekkt vörumerki í rannsóknum sem pessum pó svo að slíkt sé talið auka ytra rannsóknarréttmæti (Choi o.fl., 2013). Pessi nálgun hefur pó pann ókost að par sem auglýsingarnar eru ekki nákvæmlega eins fyrir utan nekt er möguleiki á að pað hafi haft áhrif á niðurstöðuna. Einnig gæti viðhorf pátttakenda til pessa tiltekna vörumerkis skekkt niðurstöðurnar, pó vissulega ættu slík áhrif að vera veigalítil pegar um tilraunasnið er að ræða par sem möguleg áhrif ættu pá að jafnast út á alla hópa.

Frekari rannsókna á viðfangsefninu er pörf, sér í lagi í ljósi pess að markviss aukning virðist vera í notkun kynferðistenginga meðal auglýsenda. Pessi aukning bendir til að auglýsendur séu ekki nægjanlega upplýstir um áhrif nektar á viðhorf til auglýsinga. Meðal pess sem ákjósanlegt væri að kanna eru áhrif ólíkra fyrirsæta á viðhorf til auglýsinga sem sýna nekt. Færst hefur í aukana að notaðar séu „,venjulegar“ fyrirsætur í auglýsingum í stað "fullkominna“ fyrirsæta sem hafa vöxt og útlit sem fáir geta státað af. Slíkar auglýsingar eru að ryðja sér til rúms og má par benda á auglýsingar frá hreinlætisvöruframleiðandanum Dove og fataframleiðandanum Lindex. Ahrif af notkun nektar pegar um slíkar fyrirsætur er að ræða kunna að vera önnur, mögulega jákvæðari, heldur en pegar hinar "fullkomnu“ fyrirsætur eru notaðar.

\section{Heimildir}

Alexander, M. W. og Judd, B. (1978). Do nudes in ads enhance brand recall. Journal of Advertising Research, 18(1), 47-50.

Alexander, M. W. og Judd, B. B. (1986). Differences in attitudes toward nudity in advertising. Psychology: A Quarterly Journal of Human Behavior, 23(1), 26-29.

Baker, M. J. og Churchill Jr, G. A. (1977). The impact of physically attractive models on advertising evaluations. Journal of Marketing research, 14(4) 538-555. doi: 10.1177/002224377701400411

Beard, F. K. (2003). College student attitudes toward advertising's ethical, economic, and social consequences. Journal of Business Ethics, 48(3), 217-228.

Belch, M. A., Holgerson, B. E., Belch, G. E. og Koppman, J. (1982). Psychophysiological and cognitive responses to sex in advertising. Advances in Consumer Research, 9, $424-427$.

Bello, D. C., Pitts, R. E. og Etzel, M. J. (1983). The communication effects of controversial sexual content in television programs and commercials. Journal of Advertising, 12(3), 32-42. doi: 10.1080/00913367.1983.10672846

Calfee, J. E. og Ringold, D. J. (1988). Consumer skepticism and advertising regulation: What do the polls show? Advances in Consumer Research, 15(1), 244-248.

Casler, K., Bickel, L. og Hackett, E. (2013). Separate but equal? A comparison of participants and data gathered via Amazon's MTurk, social media, and face-to-face behavioral testing. Computers in Human Behavior, 29(6), 2156-2160.

Chang, C. (2006). The influence of masculinity and femininity in different advertising processing contexts: An accessibility perspective. Sex Roles, 55(5-6), 345-356. doi: 10.1007/s11199-006-9088-x

Chang, C. T. og Tseng, C. H. (2013). Can sex sell bread? The impacts of sexual appeal type, product type and sensation seeking. International Journal of Advertising, 32(4), 559-585. doi; 10.2501/ija-32-4-559-585

Choi, H., Yoo, K., Hyun Baek, T., Reid, L. N. og Macias, W. (2013). Presence and effects of health and nutrition-related (HNR) claims with benefit-seeking and risk-avoidance appeals in female-orientated magazine food advertisements. International Journal of Advertising, 32(4), 587-616. doi: 10.2501/IJA-32-4-587-616

Choi, H., Yoo, K., Reichert, T. og LaTour, M. S. (2016). Do feminists still respond negatively to female nudity in advertising? Investigating the influence of feminist attitudes on reactions to sexual appeals. International Journal of Advertising, 35(5), 823-845. doi: 10.1080/02650487.2016.1151851

Cohen, J. (1988). Statistical power analysis for the behavioral sciences, 2nd ed. Hillsdale, NJ: Erlbaum.

Davies, J. J. (2011). TV ratings and verbal and visual sexual content in promotional ads. Journal of Promotion Management, 17(4), 378-395. doi: 10.1080/10496491.2011.597311

Dianoux, C. og Linhart, Z. (2010). The effectiveness of female nudity in advertising in three European countries. International Marketing Review, 27(5), 562-578. 
Dudley, S. C. (1999). Consumer attitudes toward nudity in advertising. Journal of Marketing Theory and Practice, 7(4), 89-96. doi: 10.1080/10696679.1999.11501854

Eaton, B. C. (1997). Prime-time stereotyping on the new television networks. Journalism og Mass Communication Quarterly, 74(4), 859-872. doi: 10.1177/107769909707400413

Egan, J. (2015). Marketing communication (2. útgáfa). London: Sage.

Eisend, M. og Tarrahi, F. (2016). The effectiveness of advertising: A meta-meta-analysis of advertising inputs and outcomes. Journal of Advertising, 45(4), 519-531. doi: 10.1080/00913367.2016.1185981

Fam, K.-S. (2008). Attributes of likeable television commercials in Asia. Journal of Advertising Research, 48(3), 418-432.

Ford, J. B. og LaTour, M. S. (1993). Differing reactions to female role portrayals in advertising. Journal of Advertising Research, 33(5), 43-53. doi: 10.1080/10641734.1996.10505042

Grazer, W. F. og Keesling, G. (1995). The effect of print advertising's use of sexual themes on brand recall and purchase intention: A product specific investigation of male responses. Journal of Applied Business Research, 11, 47-47. doi: 10.19030/jabr.v11i3.5859

LaTour, M. S. (1990). Female nudity in print advertising: An analysis of gender differences in arousal and ad response. Psychology og Marketing, 7(1), 65-81. doi: 10.1002/mar.4220070106

LaTour, M. S. og Henthorne, T. L. (1993). Female nudity: Attitudes toward the ad and the brand, and implications for advertising strategy. The Journal of Consumer Marketing, 10(3), 25-32. doi: 10.1108/07363769310041956

LaTour, M. S. og Henthorne, T. L. (1994). Ethical judgments of sexual appeals in print advertising. Journal of advertising, 23(3), 81-90. doi: 10.1080/00913367.1994.10673453

LaTour, M. S., Pitts, R. E. og Snook-Luther, D. C. (1990). Female nudity, arousal, and ad response: An experimental investigation. Journal of Advertising, 19(4), 51-62. doi: 10.1080/00913367.1990.10673200

Maciejewski, J. J. (2004). Is the use of sexual and fear appeals ethical? A moral evaluation by Generation Y college students. Journal of Current Issues og Research in Advertising, 26(2), 97-105. doi:10.1080/10641734.2004.10505167

MacInnis, D. J., Moorman, C. og Jaworski, B. J. (1991). Enhancing and measuring consumers' motivation, opportunity, and ability to process brand information from ads. The Journal of Marketing, 32-53. doi: $10.2307 / 1251955$

MacKenzie, S. B. og Lutz, R. J. (1989). An empirical examination of the structural antecedents of attitude toward the ad in an advertising pretesting context. Journal of Marketing, 53(2), 48-65.

Mehta, A. (2000). Advertising attitudes and advertising effectiveness. Journal of Advertising Research, 40(5), 67-72.

Mittal, B. og Lassar, W. M. (2000). Sexual liberalism as a determinant of consumer response to sex in advertising. Journal of Business and Psychology, 15(1), 111-127.

Muehling, D. D. og McCann, M. (1993). Attitude toward the ad: A review. Journal of Current Issues og Research in Advertising, 15(2), 25-58.

Percy, L. og Rossiter, J. R. (1992). A model of brand awareness and brand attitude advertising strategies. Psychology og Marketing, 9(4), 263-274. doi: 10.1002/mar.4220090402

Peterson, R. A. og Kerin, R. A. (1977). The female role in advertisements: Some experimental evidence. The Journal of Marketing, 41(4), 59-63. doi: 10.2307/1250235

Prendergast, G. og Hwa, H. C. (2003). An Asian perspective of offensive advertising on the web. International Journal of Advertising, 22(3), 393-411.

Prendergast, B., Liu, P og Poon, D. T. Y. (2009). A Hong Kong study of advertising credibility. Journal of Consumer Marketing, 26(5), 320-329.

Reichert, T. (2002). Sex in advertising research: A review of content, effects, and functions of sexual information in consumer advertising. Annual Review of Sex Research, 13(1), 241-273.

Reichert, T. (2007). The ageless allure: Sex, media, and marketing. Journal of Promotion Management, 13(1-2), 3-11. doi: $10.4324 / 9780203824115-2$

Reichert, T. og Carpenter, C. (2004). An update on sex in magazine advertising: 1983 to 2003. Journalism og Mass Communication Quarterly, 81(4), 823-837. doi: 10.1177/107769900408100407

Reichert, T., Childers, C. C. og Reid, L. N. (2012). How sex in advertising varies by product category: An analysis of three decades of visual sexual imagery in magazine advertising. Journal of Current Issues og Research in Advertising, 33(1), 1-19. doi: 10.1080/10641734.2012.675566

Reichert, T., Heckler, S. E. og Jackson, S. (2001). The effects of sexual social marketing appeals on cognitive processing and persuasion. Journal of Advertising, 30(1), 13-27. doi: 10.1080/00913367.2001.10673628

Reichert, T., LaTour, M. S. og Kim, J. Y. (2007). Assessing the influence of gender and sexual self-schema on affective responses to sexual content in advertising. Journal of Current Issues and Research in Advertising, 29(2), 63-77. doi: 10.1080/10641734.2007.10505217

Reidenbach, R. E. og McCleary, K. W. (1983). Advertising and male nudity: An experimental investigation. Journal of the Academy of Marketing Science, 11(4), 444-454. doi: 10.1007/BF02721927

Rife, S. C., Cate, K. L., Kosinski, M. og Stillwell, D. (2016). Participant recruitment and data collection through Facebook: The role of personality factors. International Journal of Social Research Methodology, 19(1), 69-83.

Severn, J., Belch, G. E. og Belch, M. A. (1990). The effects of sexual and non-sexual advertising appeals and information level on cognitive processing and communication effectiveness. Journal of Advertising, 19(1), 14-22. doi: 10.1080/00913367.1990.10673176 
Simpson, P. M., Horton, S. og Brown, G. (1996). Male nudity in advertisements: A modified replication and extension of gender and product effects. Journal of the Academy of Marketing Science, 24(3), 257. doi: $10.1177 / 0092070396243006$

Soley, L. C. og Reid, L. N. (1988). Taking it off: Are models in magazine ads wearing less?. Journalism Quarterly, 65(4), 960-966. doi: 10.1177/107769908806500419

Sciglimpaglia, D., Belch, M. A. og Cain, R. F. (1979). Demographic and Cognitive Factors Influencing Viewers Evaluations of Sexy Advertisements. Advances in Consumer Research 6, $62-65$.

Sparks, J. V. og Lang, A. (2015). Mechanisms underlying the effects of sexy and humorous content in advertisements. Communication Monographs, 82(1), 134-162. doi: 10.1080/03637751.2014.976236

Spears, N. og Singh, S. N. (2004). Measuring attitude toward the brand and purchase intentions. Journal of Current Issues \& Research in Advertising, 26(2), 53-66. doi: 10.1080/10641734.2004.10505164

Steadman, M. (1969). How sexy illustrations affect brand recall. Journal of Advertising Research, 9(1), 15-19.

Thornton, L., Batterham, P. J., Fassnacht, D. B., Kay-Lambkin, F., Calear, A. L. og Hunt, S. (2016). Recruiting for health, medical or psychosocial research using Facebook: Systematic review. Internet Interventions, 4, 72-81.

van Niekerk, A. og Jenkinson, A. (2013). The use of sexual controversy in South African advertising: A pragmatic analysis. Language Matters, 44(2), 29-46.

Wan, W. W., Luk, C. L. og Chow, C. W. (2014). Consumer responses to sexual advertising: The intersection of modernization, evolution, and international marketing. Journal of International Business Studies, 45(6), 751-782.

Zimmerman, A. og Dahlberg, J. (2008). The sexual objectification of women in advertising: A contemporary cultural perspective. Journal of Advertising Research, 48(1), 71-79. doi: 10.2501/s0021849908080094 


\section{Viðauki}

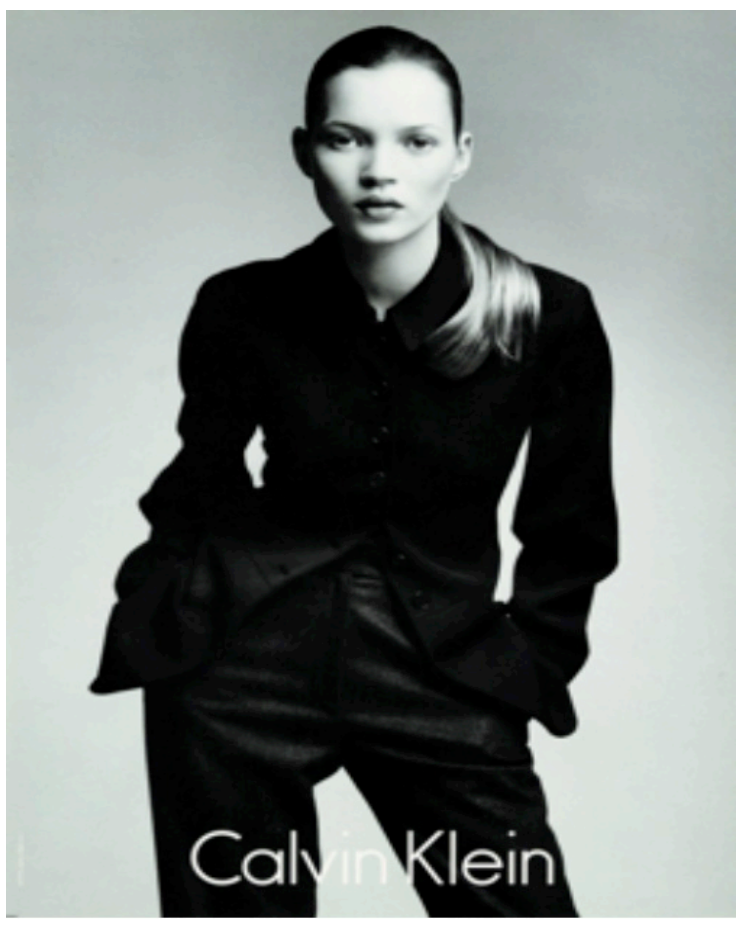

Mynd 7. Klædd kvenfyrirsæta

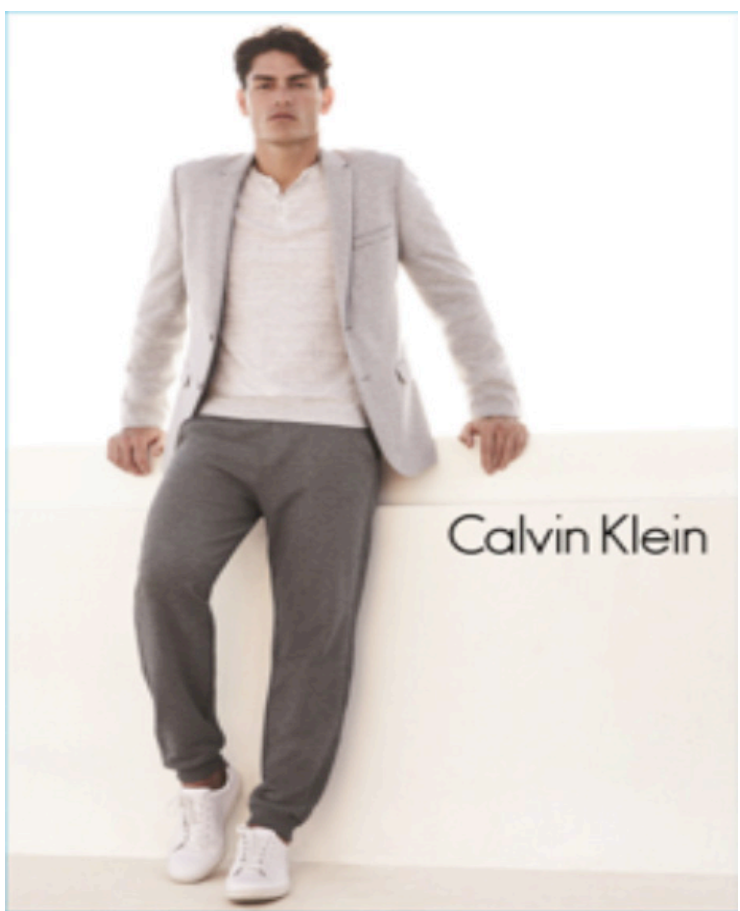

Mynd 9. Klædd karlfyrirsæta

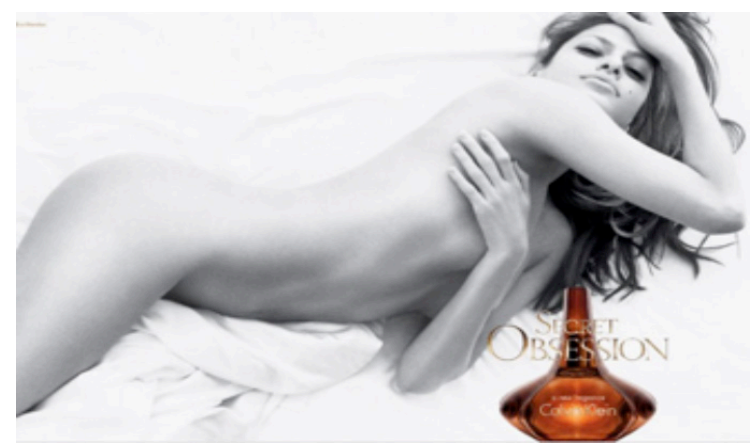

Mynd 8. Nakinn kvenfyrirsæta

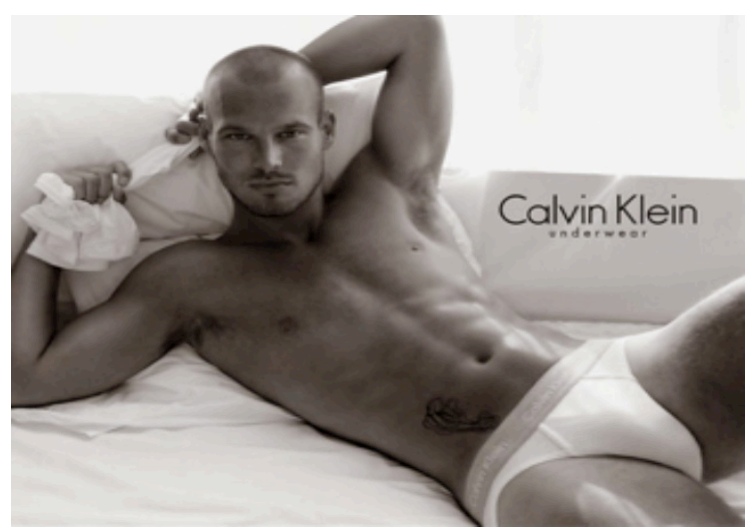

Mynd 10. Nakinn karlfyrirsæta 